\title{
Gazlı Amortisörlerde Kullanılan Mil Malzemelerine Uygulanan Farklı Yüzey İşlemlerinin Așınma Performansına Etkisi
}

\author{
Soner Savaş ${ }^{1}{ }^{*}$, Çağatay Berkan Yalçın ${ }^{2}$ \\ ${ }^{1 *}$ Erciyes Üniversitesi, Mühendislik Fakültesi, Malzeme Bilimi ve Mühendisliği Bölümü, Kayseri, 38039, Türkiye (ORCID: 0000- \\ 0002-6575-8133) ssavas@erciyes.edu.tr \\ ${ }^{2}$ Erciyes Üniversitesi, Fen Bilimleri Enstitüsü, Malzeme Bilimi ve Mühendisliği Anabilim Dalı, 38039, Kayseri, Türkiye
}

(İlk Geliş Tarihi 24.05.2021 ve Kabul Tar(h( 01.06.2021)

(DOI: 10.29228/JCHAR.51495 )

ATIF: Savaş, S., Yalcın C.B., Gazlı Amortisorlerde Kullanılan Mil Malzemelerine Uygulanan Farklı Yuzey İşlemlerinin Aşınma Performansına Etkisi, Journal of Characterization, (1) 2, 81-93, 2021.

Öz

Gazlı amortisörler, birçok uygulamada yük ve ağırlık ihtiva eden kapakları eş kuvvet ile dengelemek ve kullanım alanında hız kontrolü sağlamak, damperlemek hatta yükü kaldırmak gibi roller oynamaktadırlar. En bilinenleri; arabaların bagaj ve motor kapakları, mobilya kapakları, makina kapakları, ameliyat masaları, çeşitli endüstriyel uygulamalar, vb.'dir. Çalışma ömrünü belirleyen sızdırmazlığı sağlayan elemanlar üzerindeki tribolojik mekanizmada sürtünme ve aşınma rol oynamaktadır. Mil malzemesi ile sızdırmazlık elemanı arasındaki olaylar dizisinde mil malzemesinin yüzey pürüzlülüğü, sızdırmazlık parçası olan keçe ve O-ringlerin malzeme özellikleri etkendir. Mil malzemesinin pürüzlülüğünü iyileştirmek ve aşınmaya karşı direncini arttırmak için farklı prosesler ile yüzey özellikleri iyileştirilebilmektedir. Bu çalışmada, aynı çaplarda ve aynı özelliklerde hazırlanmış olan gazlı amortisörlerde nitrürasyon uygulanmış C35, krom kaplanmış C45 ve krom kaplanmış SS316 olmak üzere 3 farklı milin ve farklı özelliklerdeki keçelerin amortisör ömrüne olan etkisi tribolojik olarak araştırılmıştır. Yapılan testlerde yüzey pürüzlülükleri, sertlikleri, aşınma dirençleri, sürtünme kuvvetleri, ömür testlerindeki gaz kayıpları ölçülmüş ve yorumlanmıştır. Sonuç olarak en iyi amortisör ömrüne, düşük pürüzlülükteki mil ve PU keçe ile ulaşılmıştır.

Anahtar Kelimeler: Gazlı amortisör, mil yüzeyi, keçe, aşınma, çalışma ömrü.

\section{The Influence of Different Surface Treatments on Wear Performance of Rod Materials used in Gas Springs}

\footnotetext{
Abstract

Gas springs play roles in many applications, such as balancing the covers containing load and weight with equal force and providing speed control in the area of use, damping and even lifting the load. Best known
} 
applications are luggage and engine covers of cars, furniture covers, machine covers, surgical tables and different industrial applications, etc. Friction and abrasion play a role in the tribological mechanism on the sealing elements that determines the working life. The events between the rod material and the sealing element are affected by the surface roughness of the rod material, and material properties of the sealings and O-rings. To improve the roughness of the rod material and increase its resistance to wear, surface properties can be improved by different processes. In this study, the effect of the rod material and surface properties was investigated tribologically on the life of the gas springs. Three different rods were prepared with the same specifications and with the same diameter, as nitrided C35, chromium plated C45 and chromium plated SS316. Surface roughness, hardness, wear resistances, friction forces and gas losses in the life-cycle tests were measured and interpreted. As a result, the best gas spring life is achieved with lowroughness rod and with PU seal.

Keywords: Gas spring, rod surface, seal, wear, life-cycle.

\section{Giriş}

Son yıllardaki bilimsel gelişmeler 1şığında tribolojik olayların daha iyi anlaşılması ve önem verilmesi ile sanayi ürünlerinin ve makine elemanlarının kullanım ömürlerini dolayısıyla kalitelerini arttırmak yönünde çalışmalar yapılmaktadır. Yılda 80 milyar \$ hacmine ulaşan ara yüzey etkileşiminden kaynaklanan kayıp maliyetinin 20 milyar \$'lık kısmının piston segmanı/silindir yataklama parçalarından kaynaklandığı ifade edilmektedir [1]. Gazlı amortisörlerde de mil yüzeyi boyunca çalışan sızdırmazlık ve yataklama elemanlarının oluşturduğu tribolojik olaylar, bu parçaların en önemli unsurlarından biri olan kullanım ömürlerini doğrudan etkilemektedir.

Uluslararası pazardaki birçok gazlı amortisör üreticisinin birbirine çok yakın tasarımlarda üretimler yapmasına karşın ürünleri için sundukları kullanım ömürleri konusunda büyük bir rekabet söz konusudur. Tasarımlar çok yakın olmasına karşın farklılık ise, yüzey mühendisliği alanındaki iyileştirmeler, sızdırmazlık parçalarının tasarımları ve malzeme seçimleridir. Ülkemizde gazlı amortisör sektöründe hem ulusal pazarda hem de uluslararası pazarda rekabet edebilmek için sanayinin yüzey mühendisliği alanında çalışmalara ihtiyacı açıktır. Ayrıca ağır metal sektörüne dahil olduğundan üretilen ürünlerin kullanım ömrü ekolojik olarak da evrensel bir öneme sahiptir. Gazlı amortisörler genellikle yükü kaldırma, kaldırmayı kolaylaştırma, indirme fonksiyonunda yük dengeleme, hareketin son aşamasını yavaşlatıp ani çarpma etkisini sönümleme vb. amaçlar ile kullanılan mekanizmalardır. Gazlı amortisör diğer bir tanımla, silindir şeklinde gaz basıncı olan kapalı bir hacimde mil hareketi esnasında sızdırmazlığı sağlamak için keçe ve Oring gibi sızdırmazlık parçalarının kullanıldığı makine elemanlarıdır (Şekil 1).

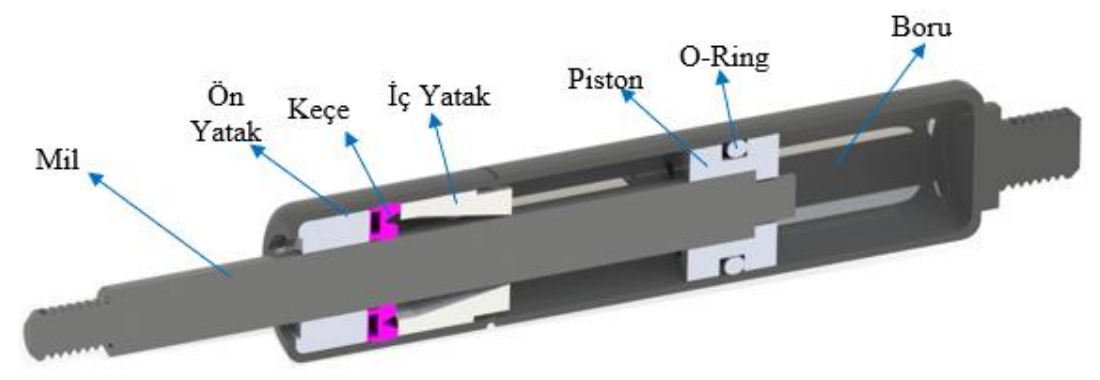

\section{Şekil 1. Gazlı amortisörün genel yapısı (mil, boru, yataklama parçaları, keçe, O-ring, piston)}

Milin iç hacme doğru ilerlemesi ile sıkıştırılabilen gaz hacmi azaldıkça, yani amortisör kapandıkça iç basınç artar. Gaz her zaman daha büyük bir hacme geçmek isteyeceğinden, mile dışarı yönde bir itme kuvveti sağlar. Standart gazlı amortisörlerin yükü itme veya kaldırma gibi fonksiyonu, gazların sıkıştırılabilir olması özelliğinden gelmektedir. Bu fiziksel fonksiyon, gazlı amortisörlerin ana çalışma mekanizmasıdır. Öte yandan bu mekanizma içerideki basıncın korunabileceği kadar bir ömre sahip olacaktır. Dolayısıyla amortisörlerin ömrüne etki edebilecek en önemli nokta sızdırmazlık fonksiyonuna etki edebilecek tüm parametreleri kapsamaktadır.

Milin tam olarak dışarıda olduğu durum açık boy, milin tam olarak içeride olduğu durum kapalı boy ölçülerini belirler. Kapalı boy ile açık boy arasındaki milin çalışma mesafesi ise "çalışan boy" olarak ifade 
edilir. Gazlı amortisör her kapanıp açıldığında sızdırmazlık parçaları ve mil yüzeyi arasında meydana gelen tribolojik olaylar nedeniyle gaz ve yağ kaybı yaşanır. Gazlı amortisörün toplam basıncının genellikle \%10'u veya uygulamaya göre talep edilen yüzde miktarında gaz basıncı kaybedene kadar sağlayabildiği açmakapama sayısı "çalışma ömrü" olarak ifade edilir. Bunun yanı sıra sürtünme kuvveti de amortisörün tüm çalışması boyunca açma ve kapama arasındaki kuvvet farklılığını önemli ölçüde etkilediğinden, dikkat edilmesi ve tolerans içinde kontrol altına alınması gereken bir etkendir. Şekil 2'de 1'den 3'e doğru amortisörün kapanma hareketi gösterilmiştir. Mil içeriye ilerledikçe içerideki boş hacim mil hacmi kadar daraldığından gaz basıncı artmaktadır.

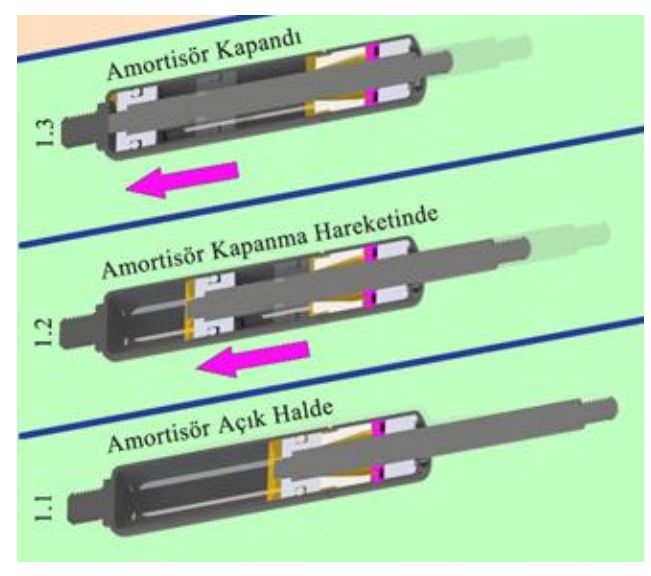

Şekil 2. Gazlı amortisörün kapanma hareketi

Gazlı amortisörler otomotiv sektöründe bagaj ve kaput kapaklarında, denizcilik sektöründe gemi ve yatlarda yukarı yönde açılan kapaklarda, mobilya sektöründe mutfak dolabı kapakları, yukarı yönlü açılıp kapanan yataklarda ve baza mekanizmasında, medikal sektörde hasta ve ameliyat yataklarında, fizyoterapi aletlerinde, medikal yemek masalarında, matbaa sektöründe baskı makinalarında, tarım sektöründe, uzay araçlarında, savunma sanayisinde ve endüstriyel bir çok uygulamada önemli ve fonksiyonel rol almaktadır. Otomotiv sektörüne bakıldığında 1928 yılından bugüne dek gazlı amortisör kullanımı yaygınlaşmış ve bugünlere kadar aynı fiziksel çalışma prensibi ile üretilmektedir. Otomotiv sektörüne Avrupa'nın en büyük hacminde amortisör üreticilerinden olan Stabilus firması resmî web sitesinde yayınladığı finansal raporuna göre 2018 yılında 125 milyon'un üzerinde gazlı amortisör üretimi ile 962,6 milyon Euro'luk cirosuna \%6 büyüme ile ulaşmıştır. Yine bu raporda, $\% 63$ oranında otomotiv sektörüne, $\% 37$ oranında ise diğer endüstri sektörlerine üretim yaptığı açıklanmıştır [2].

Sakarya ve ark. [3] yaptıkları çalışmada gazlı amortisörde kullanılan keçe tasarımında yalnızca hidrolik basınç uygulayarak $311 \mathrm{~km}$ boyunca ömür testi gerçekleşmişlerdir. Bu çalışmada PU keçe ve 0.879 $\mathrm{g} / \mathrm{cc}$ yoğunlukta yağ kullanılmıştır. Ömür testi ise $80^{\circ} \mathrm{C} \pm 2$ sıcaklık, $0,4 \mathrm{~m} / \mathrm{sn}$ açma-kapama hızı ve $250 \pm$ 2 bar basınç altında gerçekleştirilmiştir. Testin sonucunda ortalama sızıntı $0,023 \mathrm{cc} / 100 \mathrm{~m}$ olarak ölçülmüştür. Dolayısıyla yağ kaybının çalışma ömrü boyunca ne kadar olabileceği konusunda rakamsal veri ortaya koymuşlardır. Ayrıca keçedeki iç dudak üzerinde meydana gelen deformasyonun \%50 seviyelerinde olduğunu ifade etmişlerdir. Yildiz ve ark. [4] bagaj kapağının gazlı amortisör ile açmakapama mekanizmasını teorik ve deneysel olarak incelenmişlerdir. Gazlı amortisörün yükü kaldırma fonksiyonu etkisinde, bagajı açmak/kapamak için gereken el kuvvetini modellemişlerdir. Ancak gazhı amortisörler sahip oldukları boş hacmin genellikle \%20'si kadar yağ, \%80'i kadar sıkıştırılmış azot gazı ihtiva etmektedir. Bu çalışmada da yapılacak olan ömür testlerinde amortisörün dibinde konik bir havuz kullanılmış, dolayısıyla kaçan yağ miktarı bu havuzdan şırınga ile çekilerek tespit edilebilmiştir. Ömür testinin anlatıldığı kısımda bu konuya daha detaylı değinilmiştir. Dolayısıyla yağ kaybı olup/olmadığı dikkate alınmış olacaktır. Boblet ve ark. [5] yapmış oldukları çalışmada C35 ile yakın özelliklerde olan C45 mil malzemesi üzerinde $\mathrm{QPQ}^{\circledR}$ nitrürasyon prosesini gerçekleştirdikleri, ticari olarak TUFFTRIDE ${ }^{\circledR}$ olarak isimlendirdikleri üretim reçetesini Şekil 3'teki gibi TT diyagramı ile anlatmışlardır. Bu çalışmada da, HEF firması tarafından ilgili $\mathrm{QPQ}^{\circledR}$ reçetesi uygulanmış nitrürasyonlu miller kullanılmıştır. Bengisu ve ark. [6]'nın yapmış oldukları çalışmada ifade edildiği gibi, sürtünme aslında hem etkileşimli yüzeylerin arayüz özelliklerine hem de onları içeren sistemin dinamiğine bağlıdır. Mikroskobik seviyede, yüzeyler birbirine göre hareket ettikçe gerçek temas alanı değişir. Böylece makroskopik düzeyde, toplam sürtünme ve normal 
kuvvetler zamana bağlı olaylardır [6]. Amortisör için bu durum değerlendirildiğinde mil çapı arttıkça sızdırmazlık ile ilgili yüzey alanı artacağından daha fazla sürtünme meydana geleceği ve ayrıca çalışma hızının da aynı amortisörde farklı ömürler sunabileceği öngörülmektedir.

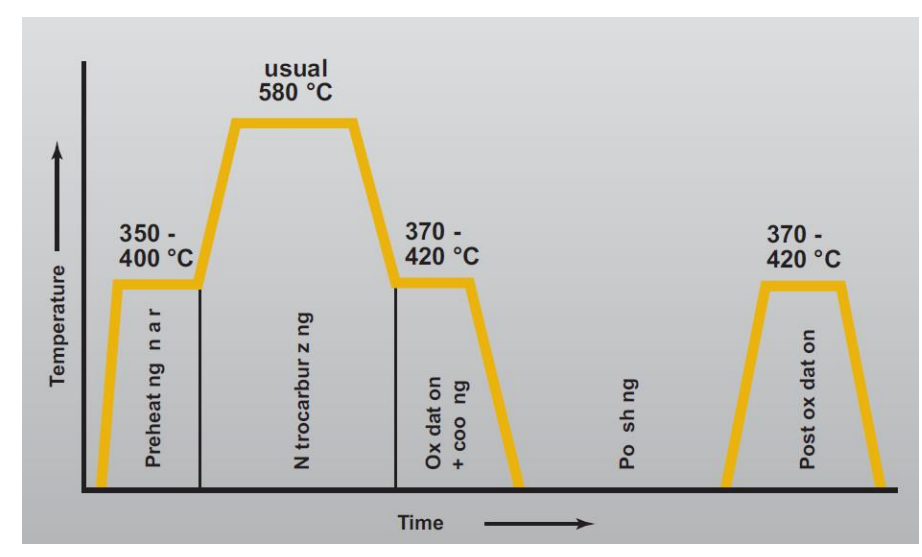

Şekil 3. TUFFTRIDE ${ }^{\circledR}$ ticari ismi ile QPQ prosesi TT (zaman-sicakllk) diyagramı [5]

Boblet ve ark. [5] yine aynı çalışmada korozyon dayanımını incelemek ve karşıllaştırmak için ısıl işlem görmemiş C45, $17 \mu \mathrm{m}$ QPQ, $20 \mu \mathrm{m}$ ve $40 \mu \mathrm{m}$ krom kaplama ile $20 \mu \mathrm{m}$ nikel kaplamalı C45 millerine EN ISO 9227:2006 NSS standardına göre tuz testi uygulamışlardır. Tuz testi dayanımının diğer örneklere göre 5 kat arttığı görülmüştür. Maliyet olarak da değerlendirildiğinde QPQ prosesi diğer alternatiflerine göre daha uygundur. Devlen ve ark. [7]'nın yapmış oldukları çalışmada belirtildiği gibi PTFE ürünler diğer malzemelere (NBR, PU vb.) kıyasla daha düşük sürtünmeler ve daha uzun ömür avantajları sunmaktadır. Çalışma kapsamında PTFE keçe her ne kadar çalışılmamış olsa da, NBR ve PU keçeler bu çalışmada test edilecek, dolayısıyla başka bir çalışma için karşılaştırma değeri taşıyacaktır. Cai ve ark. [8]'nın yapmış oldukları çalışmada farklı sürelerde nitrürasyon işlemi uygulanmış ve uygulanmamış C45 çeliği üzerindeki aşınma dayanımı incelenmiştir. Aynı aşınma koşullarında C45 çeliği 0,14 g kütle kaybı verirken, 120 dak nitrürasyon işlemi yapılmış $\mathrm{C} 45$ çeliğinin ise $0,0029 \mathrm{~g}$ kütle kaybı verdiğini bulmuşlardır. 90 dak ve üzeri uygulanan diğer nitrürasyonlu millerde de çok yakın sonuçlar görülmektedir. Aşınma karakterindeki iyileşmeyi ise nitrürasyon prosesinde oluşan azot difüzyonu sonucu tabakadaki $\varepsilon-\mathrm{Fe}_{3} \mathrm{~N}$ 'ün yüzey sertliğini arttırmasına, $\mathrm{Fe}_{3} \mathrm{O}_{4}{ }^{\prime}$ in ise sürtünme katsayısını düşüren bir karakter kazandırmasına dayandırmışlardır. Lee [9] yapmış olduğu çalışmada iki farklı iç çapa sahip keçeyi test etmiş, Ø20xØ8 ölçülerindeki keçe için $1.405 \mathrm{kgf}(\sim 13,8 \mathrm{~N})$ ve Ø20xØ10 ölçülerindeki keçe için 1,450 kgf ( 14,21 N) sürtünme kuvveti değerleri bulmuştur. Bu durum göstermektedir ki mil çapı değişikliği, aynı keçe malzemesi ve dudak kesit tasarımı kullanılsa dahi sürtünme kuvvetinde etkendir. Farklı çapta mil tasarımları için aynı keçe tasarımlarındaki sürtünme kuvveti farklılıkları da ayrıca çalışılmaya ve modellenmeye açıktır. Benedetto ve ark. [10] yapmış oldukları çalışmada keçe malzemesinin, uygulama yerinde, uygulama ömrünü belirleyen en kritik parça olduğunu vurgulamışlardır.

Bu çalışmanın konusu gazlı amortisörlerde 3 farklı mil malzemesinin ve farklı özelliklerdeki keçelerin amortisör ömrüne olan etkisinin tribolojik olarak araştırılmasıdır. Kullanılacak olan miller nitrürasyon uygulanmış C35, krom kaplanmış C45 ve krom kaplanmış SS316'dır. Keçeler ise 90 ShR sertlikte olan NBR ve PU malzemelerden tercih edilmiştir.

\section{Materyal ve Metot}

\subsection{Malzemeler}

$\mathrm{Bu}$ çalışma kapsamında hazırlanan amortisör numunelerinde kullanılan bazı malzemeler ve teknik detaylar şu şekildedir. Mil malzemeleri: 1. Nitrürasyonlu C35 mil (QPQ $\left.{ }^{\circledR}\right), 2$. Krom kaplamalı C45 mil, 3. Krom kaplamalı SS316 mil. Keçe malzemeleri: 1. 90 ShR NBR keçe (Tablo 1) [11], 2. 90 ShR PU keçe (Tablo 1) [12]. Yăg: Shell Spirax S2 ATF AX (Tablo 2) [13]. Nitrürasyonlu C35 mil numuneleri, taşlama ve ovalama prosesleri ile dış yüzeyde hassas toleranslar içerisinde üretildikten sonra nitrürasyon prosesi uygulanmıştır. Nitrürasyon prosesinde ise $350-400{ }^{\circ} \mathrm{C}$ 'de ön 1 sitmadan sonra $580{ }^{\circ} \mathrm{C}$ 'de cyanate tuzundan 
azot kopartılıp demir nitrür olarak malzeme yüzeyinde difüzyon 90 dak boyunca devam ettirilir. Bu aşama tuz nitrürasyon olarak bilinir. Akabinde $370-420{ }^{\circ} \mathrm{C}$ aralığında oksidasyon, oda sicaklığında polisaj ve son işlem olarak $370-420^{\circ} \mathrm{C}$ aralığında yeniden oksidasyon işlemi uygulanmıştır. Nitrürasyonlu mil numunesi kesilerek bakalite alınmıştır. Şekil 4'te nitrürlenmiş C35 milin ve nitrürasyon tabakasının kesit SEM görüntüsü verilmektedir. Nitrürasyon sonucunda C35 çelik malzemesinde yaklaşık $15 \mu \mathrm{m}$ tabaka kalınlığg ölçülmüş, belirgin bir beyaz tabakaya rastlanılmamıştır. Krom kaplamalı C45 mil numuneleri ise, C45 malzemesine elektroliz yöntemi ile krom kaplama uygulanarak hazırlanmıştır. Kaplama kalınlığ yapılan ölçümlerde yaklaşık $12 \mu \mathrm{m}$ olarak ölçülmüştür (Şekil 5). SS316 (AISI 316) malzemesine de krom kaplama uygulanmıştır. Kaplama sertliği ISO 409/2 standardına göre 927 HV(0.2) olarak ölçülmüştür.

Tablo 1. NBR 90ShR ve PU 90ShR keçelerin özellikleri

\begin{tabular}{|c|c|c|}
\hline NBR 90ShR Keçe Özelliği & Metot & Dĕger \\
\hline Sertlik, Tip A & ASTM D2240 & 89 \\
\hline Çekme mukavemeti (MPa) & ASTM D412 & 19 \\
\hline Elastiklik (\%) & ASTM D412 & 106 \\
\hline EO14 IRM 901 yağ, sertlik değişimi & ASTM D471 & 3 \\
\hline EO34 IRM 903 yağ, sertlik değişimi & ASTM D471 & -8 \\
\hline PU 90ShR Keçe Ö̈zelliği & Metot & De ̌̆er \\
\hline Sertlik, Tip A & DIN 53505 & 92 \\
\hline Çekme mukavemeti (MPa) & DIN 53504 & 51 \\
\hline Elastiklik modülü (MPa) & DIN 53504-S2 & 12 \\
\hline Abrazyon kaybı $\left(\mathrm{mm}^{3}\right)$ & DIN ISO 4649-A & 30 \\
\hline Kırılma uzaması (\%) & DIN 53504 & 460 \\
\hline
\end{tabular}

Tablo 2. Gazlı amortisörlerde kullanılan yă̆ın özellikleri

\begin{tabular}{|c|c|c|}
\hline Shell Spirax S2 ATF AX Özelliği & Metot & Dĕger \\
\hline Kinematik viskozite $\left(\mathrm{mm}^{2} / \mathrm{s}\right)$ & ISO3104 (@40C) & 34.6 \\
\hline Kinematik viskozite $\left(\mathrm{mm}^{2} / \mathrm{s}\right)$ & ISO3104(@100C) & 7,1 \\
\hline Viskozite indeksi & ISO 2909 & 174 \\
\hline Yoğunluk $\left(\mathrm{kg} / \mathrm{m}^{3}\right)$ & ISO12185 (@15 ㄷ) & 874 \\
\hline Parlama noktası $\mathrm{COC}\left({ }^{\circ} \mathrm{C}\right)$ & ISO 2592 & 180 \\
\hline Akma noktası $\left({ }^{\circ} \mathrm{C}\right)$ & ISO 3016 & -45 \\
\hline
\end{tabular}

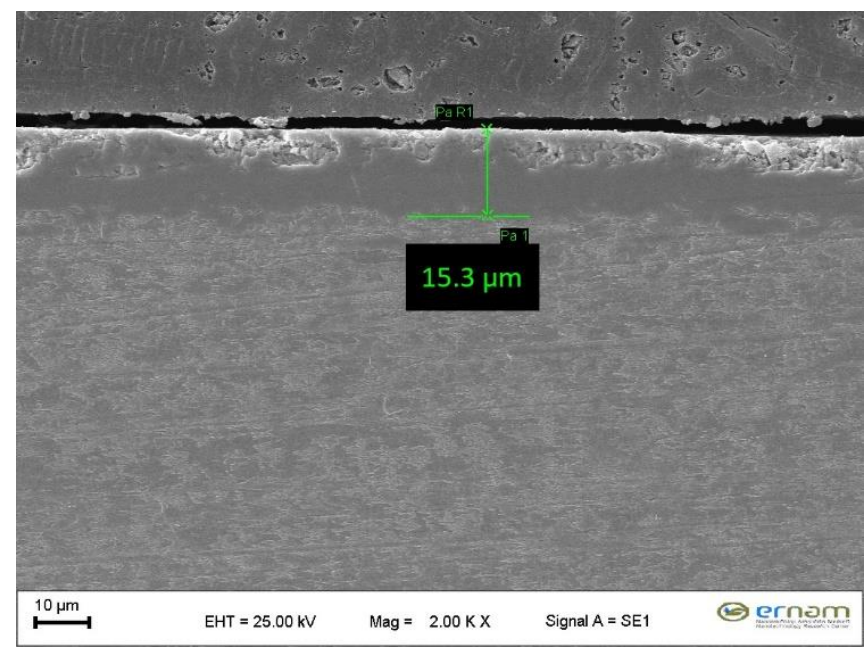

Şekil 4. Nitrürlenmiş C35 milin ve nitrürasyon tabakasının kesit SEM görüntüsü (kalınlık 15 


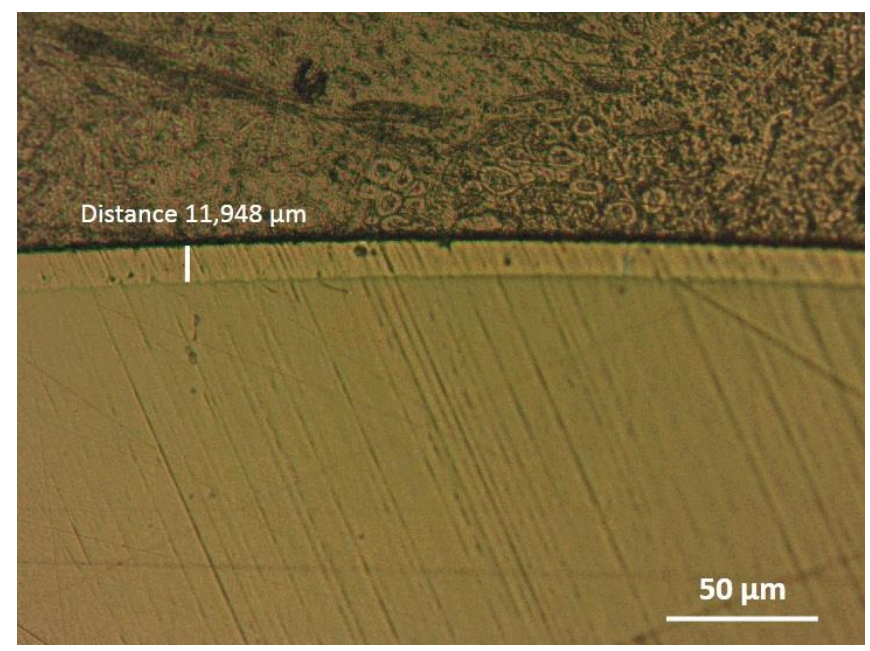

Şekil 5. Krom kaplı C45 milin ve kaplama tabakasının kesit optik mikroskop görüntüsü (kalınlık 12 $\mu$ m)

Gazlı amortisörlerin çalışma ömrünü belirlemek için açma-kapama (çevrim) testleri yapılmaktadır. $\mathrm{Bu}$ açma-kapama testleri esnasında belirli açma-kapama aralıklarında (örneğin 30.000 açma-kapama testinde başlangıçta ve her 5.000'de bir) amortisörün kaybettiği yağ, kuvvet (F1, F2, F3, F4), sürtünme kuvveti (FR), mil yüzey pürüzlülüğü $\left(\mathrm{R}_{\mathrm{a}}\right)$ kayıt altına alınmaktadır. Mil yüzey pürüzlülüğü, keçe aşınmasına doğrudan etki eden bir faktördür. $\mathrm{Bu}$ nedenle amortisörlerde mil yüzey pürüzlülüğü kontrol altında tutulmakta ve amortisör ömrünü arttırabilecek keçe malzemesi ile yüzey pürüzlülügü ilişkisi araştırılmaktadır. $\mathrm{Bu}$ çalışmada Mitutoyo Surftest SJ-210 portatif yüzey pürüzlülük ölçüm cihazı kullanılarak yüzey pürüzlülükleri ölçülmüştür.

\subsection{Amortisör Kuvvet Ölçümleri}

Kuvvet ölçümünde ZWICK FB020 üniversal amortisör kuvvet ölçümü test cihazı kullanılmıştır. Amortisör mili açık pozisyonda iken cihaza yerleştirilir. Basma/çekme test cihazlarına benzer şekilde bir fotosel tepki kuvvetini bilgisayara iletmektedir. Fotosel okuması sonucunda bilgisayar Newton olarak kuvvet ölçümünü vermektedir. İlk $5 \mathrm{~mm}$ amortisör kapatıldıktan sonra 5 sn beklenir. Bu bekleme süresi, amortisör içerisinde konum değiştiren pistonun ön tarafından arka tarafına doğru gaz geçişi için verilen zamandır. $5 \mathrm{~mm}$ pozisyonuna gelinip 5 sn beklendiğinde sabit konumdayken okunan kuvvet belirli bir miktar düşer ve pistonun ön ve arka tarafındaki basıncın dengelenmesi ile sabitlenir. Okunan bu sabitlenmiş ilk değer statik bir ölçüm sonucu olarak F1 olarak tanımlanır.

Daha sonra boy mesafesinin son $5 \mathrm{~mm}$ 'sine kadar dinamik olarak ilerleme ve ölçüm yapılır. Boy mesafesinin son 5 mm'sine gelindiğinde tekrar 5 sn beklenir ve statik olarak F2 değeri okunur. Amortisör son $5 \mathrm{~mm}$ için de ilerler. Artık amortisör tamamen kapanmış konumdadır. Şimdi ise test cihazı amortisörün açılmasına izin verecek şekilde yukarı doğru hareket eder ve $5 \mathrm{~mm}$ sonra durup statik olarak değer okunur. $\mathrm{Bu}$ değer ise F4'tür. F4 okunduktan sonra dinamik olarak amortisörün açılmasına devam edilir. Son 5 mm kala yeniden statik ölçüm yapılır. Ölçülen bu değer ise F3 olarak tanımlanır (Şekil 6).

$$
F_{1}-F_{3}=F_{2}-F_{4}=F_{R}(\text { Sürtünme Kuvveti })
$$

Elde edilen bu 4 kuvvet değerinden yukarıdaki formül ile sürtünme kuvveti hesaplanır. Amortisörün F2 ile F1 kuvveti arasındaki oran ise yaylanma olarak ifade edilen katsayıyı verir. Yaylanma bir amortisörün açık halde iken sahip olduğu kuvvetin, kapalı hale geldiğinde kaç katı bir kuvvete çıkacağını ifade eder.

$$
\frac{F_{2}}{F_{1}}=X(\text { Yaylanma Katsayıs })
$$




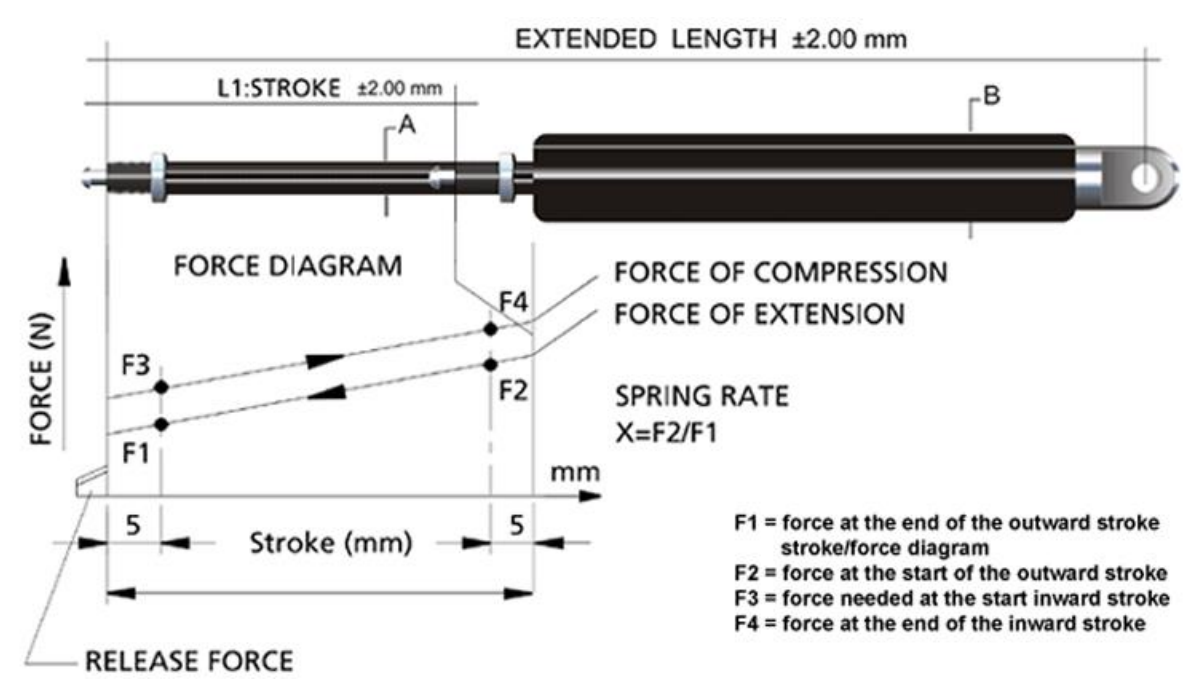

Şekil 6. Gazlı amortisör kuvvet ölçümü diyagramında F1, F2, F3, F4 noktaları

\subsection{Açma-Kapama (Çevrim) Testleri}

Ömür testi olarak da bilinen açma-kapama çevrim testleri, amortisörlerin kaç açma-kapama çevrimi sonunda sahip olduğu F1, F2, F3, F4 ve FR kuvvetlerini belirlenen yüzde oranında veya talep edilen kuvvet limitlerine ulaşana kadar çalışabildiği çevrim sayısıdır. Her bir açma-kapama hareketi amortisörün çalışan mil uzunluğu yani boy olarak ifade edilen ölçüsünün 2 katı kadardır. Örneğin uygulama yerinde \%10 F1 gaz kaybına kadar çalışabilecek $100 \mathrm{~mm}$ boy ölçüsündeki bir amortisör, ömür testi sonucunda 50.000 çevrime kadar \%10 gaz kaybına yaklaşmış ise, bu amortisörün çalışma ömrünün 100.000 boy olduğu dolayısıyla 100.000 x $100 \mathrm{~mm}$ sonucunda $10 \mathrm{~km}$ kadar bir aşınma söz konusu olduğu söylenir. Ömür testi boyunca, kuvvet değişimini takip etmek için belirli periyotlarda amortisör sökülüp, ZWICK kuvvet ölçme test cihazına bağlanıp hassas kuvvet ölçümleri yapılmaktadır. Daha sonra yeniden ömür testi cihazına bağlanan numune ile teste devam edilir. Bu ölçümler ise teste başlamadan önce ve belirlenen çevrim periyotlarında gerçekleştirilir. Talep edilen yüzde gaz kaybı elde edilene kadar test bu şekilde sürdürülür. $\mathrm{Bu}$ çalışmada kullanılan ömür testi cihazı Global Amortisör (İstanbul) firması tarafindan imal edilmiş olup, pnömatik pistonlar, manyetik sensörler ve elektronik kart vasıtası ile açma-kapama hareketi yaptırılmakta ve elektronik olarak kaç açma-kapama yaptığı kaydedilmektedir. Gazlı amortisör pnömatik kafa ile sabit kafa arasında sabitlenir. Belirli hızda açma-kapama yapılır. Belirli periyotlarda bir sökülerek bazı ölçümler ve incelemeler yapılarak yeniden cihaza bağlanıp süreç devam ettirilir. İlk, son ve her bir çevrim aralı̆̆ında amortisörün kaybettiği yağ miktarı, F1-F2-F3-F4-FR değerleri, mil yüzey pürüzlülüğü ve görsel mil yüzey kontrolü sağlanır.

İncelemeler şu şekilde özetlenebilir. Kuvvet Değerleri: Sürtünme kuvvetinin, F1-F2-F3-F4 kuvvetlerinin ölçümü ise Zwick test metodu ile sağlanır. Ömür testi boyunca uygulanan açma-kapama hızı ve ortam sıcaklığı sabit tutulur. Bu bilgiler ışığında genel olarak \%15 gaz kaybı elde edilene kadar elde edilen çevrim süresi amortisörün kullanılabilir ömründe belirleyici rol oynar. Yağ Kaybı: Amortisörden kaçan yağın biriktiği havuzda toplanan yağ miktarı, çizgi referansları dikkate alınarak veya şırınga ile çekilerek ölçülmesi ile her bir çevrimde kaçan yağ miktarı tespit edilir. Tribolojik olarak mil yüzeyi ile keçe arasında sürtünmeyi azaltıcı rol oynayan yağ kaybı hızı, amortisörün yağsız kalabileceği ömrü belirlemede rol oynar. Genellikle talep edilen maksimum kuvvet kaybı bu süreden daha kısa sürdüğünden amortisör ömrünü belirlemek için kuvvet değerleri daha belirleyici rol alacaktır. Yağın kalitesi ise mil yüzey pürüzlülüğ̈nnün çalışma süreci boyunca etkisi ile keçe malzemesine olan kimyasal etkisi dikkate alınması gereken bir başka konudur. Yağın kimyasal özellikleri, kuvvet değerleri ve yüzey pürüzlülüğüne doğrudan etki etmektedir. Yüzey Pürüzlülüğü: Test öncesinde ve sonrasında her bir çevrim sonucunda mil yüzey pürüzlülüğü ölçümü yapılır. Görsel olarak da mil yüzeyinde beyaz ışık altında herhangi bir çizik, deformasyon, iz oluşumu olup olmadığı kontrol edilir. Bu bilgiler ışığında mil yüzeyi kalitesinin çalışma süresi boyunca değişimi izlenir. 
Bu çalışmada yapılan tüm ömür testi deneylerinde \%10 gaz kaybına ulaşana kadar her 5.000 çevrimde bir Zwick kuvvet ölçümleri yapılmıştır. Testlerde amortisörün üretimi ile, etkisinin araştırılacağı değişken tutulacak parametreler hariç diğer tüm özellikleri aynı olacak şekilde; 3 farklı mil yüzeyinin, aynı NBR keçe kullanımında mil yüzey özelliğindeki değişkenlerin etkileri ve 2 farklı keçenin, aynı yüzey özelliklerdeki QPQ mil kullanımında keçe malzemesinin değişkenlerinin etkileri ayrı ayrı çalışılmıştır. Amortisörün ömür testine olan etkisi, mil yüzeylerindeki pürüzlülüğün etkisi, amortisörün sürtünme kuvvetindeki değişim, sızdırmazlık, vb. etkenler üzerinde çalışma yapılmış ve sonuçlar yorumlanmıştır. En yaygın gazlı amortisör mil çapları Ø4, Ø6, Ø8, Ø10, Ø12, Ø14, Ø20 ve Ø22 mm ölçülerindedir. Bu çalışmada, $\varnothing 8 \mathrm{~mm}$ mil çapı ve $\varnothing 18 \mathrm{~mm}$ boru çapındaki standart bir amortisör ürünü kullanılmıştır. Tüm parametreler eşit olacak şekilde mil malzemesi, yüzey kaplaması, keçe malzemesi değişkenliğinde çalışma yapılmış ve her numunenin çalışma ömrü tespit edilmiştir.

\section{Bulgular}

\subsection{Mil Yüzey Pürüzlülüğünün Amortisör Ömrüne Olan Etkisi}

Mil yüzey pürüzlülüğünün amortisör ömrüne olan etkisini analiz etmek için Tablo 3'teki amortisör özelliklerinde Tablo 4'teki gibi 3 farklı numuneden 3'er adet hazırlanıp ömür testi uygulanmıştır. Bu numunelerde tüm değişkenler aynı, yalnızca mil malzemeleri ve kaplamaları farklıdır.

Tablo 3. Test edilecek amortisörlerin özellikleri

\begin{tabular}{ll}
\hline$\ddot{\text { Özellik }}$ & Değer \\
\hline Mil & $\emptyset 8 \mathrm{~mm}$ \\
Boru İç Çap1 & $\emptyset 16 \mathrm{~mm}$ \\
Keçe & NBR $90 \mathrm{ShR}$ \\
Kuvvet & $600 \mathrm{~N}$ \\
Çalışan Boy & $202 \mathrm{~mm}$ \\
Yağ Viskozite İndeksi & $174(\mathrm{ISO} 2909)[13]$ \\
Yağ Kinematik Viskozite $\left(40^{\circ} \mathrm{C}\right)$ & $34,6 \mathrm{~mm}^{2} / \mathrm{s}[13]$ \\
\hline
\end{tabular}

Tablo 4. Numune kodlama yapısı

\begin{tabular}{lll}
\hline Numune Kodlamast & Ana Mil Malzemesi & Yüzey Kaplamast \\
\hline CNxx & C35 & Nitrürasyon \\
CCxx & C45 & Krom Kaplama \\
SCxx & SS316L & Krom Kaplama \\
\hline
\end{tabular}

“xx” ile ifade edilen kısım numune no ’sunu belirtmiş ve her numuneden 3 'er adet hazırlanmıştır.

Mil malzemesinin değişkenliğinde diğer parametreler sabit tutulduğunda test öncesi ve sonrası mil yüzey pürüzlülükleri ile yüzde olarak gaz kaybı sonuçları numune bazında Tablo 5 'te sunulmuştur.

Tablo 5. Test öncesi ve sonrası yüzey pürüzlülükleri ölçümleri ve gaz kayıpları

\begin{tabular}{|c|c|c|c|c|c|}
\hline \multirow[b]{2}{*}{$\begin{array}{l}\text { Numune } \\
\text { Kodu }\end{array}$} & \multirow[b]{2}{*}{$\begin{array}{l}\text { Mil } \\
\text { Malzemesi }\end{array}$} & \multirow{2}{*}{$\begin{array}{l}\text { Isşlem / } \\
\text { Kaplama }\end{array}$} & \multirow{2}{*}{$\begin{array}{l}\text { Test Öncesi } \\
\text { Yüzey Pürü̈lü̈lüğ̈̈ } \\
R_{a}(\mu m)\end{array}$} & \multicolumn{2}{|l|}{ Test Sonrast } \\
\hline & & & & $\begin{array}{l}\text { Yüzzey Pürüzlülü̈̆̈̈̈ } \\
R_{a}(\mu m)\end{array}$ & $\begin{array}{l}\text { Gaz Kaybi } \\
\text { (\%) }\end{array}$ \\
\hline CN01 & $\mathrm{C} 35$ & Nitrürasyon & 0,090 & 0,075 & 10,01 \\
\hline CN02 & $\mathrm{C} 35$ & Nitrürasyon & 0,090 & 0,080 & 10,69 \\
\hline CN03 & $\mathrm{C} 35$ & Nitrürasyon & 0,080 & 0,095 & 8,92 \\
\hline $\mathrm{CC} 01$ & $\mathrm{C} 45$ & Krom Kap. & 0,070 & 0,075 & 9,68 \\
\hline $\mathrm{CC} 02$ & $\mathrm{C} 45$ & Krom Kap. & 0,070 & 0,065 & 7,39 \\
\hline $\mathrm{CCO} 3$ & $\mathrm{C} 45$ & Krom Kap. & 0,065 & 0,090 & 10,55 \\
\hline SC01 & SS316L & Krom Kap. & 0,055 & 0,060 & 5,51 \\
\hline $\mathrm{SC} 02$ & SS316L & Krom Kap. & 0,065 & 0,070 & 9,72 \\
\hline $\mathrm{SC} 03$ & SS316L & Krom Kap. & 0,055 & 0,090 & 8,69 \\
\hline
\end{tabular}


Yüzey pürüzlülüklerindeki ortalama değişimler incelendiğinde, 50.000 çevrim ömür testi sonucunda $0,02 \mu \mathrm{m}$ boyutunda değişimler izlenmiştir. Yüzey pürüzlülüğündeki değişim Şekil 7'de grafikleştirilmiştir. Nitrürasyonlu millerin yüzey pürüzlülüğü krom kaplamalı olanlara göre daha yüksek ölçülmüşsür. Buna karşın krom kaplamalı numunelerde yüzey pürüzlülüğü artış eğiliminde iken, nitrürasyonlu milde artış ve düşüş eğiliminde olduğu görülmüştür.

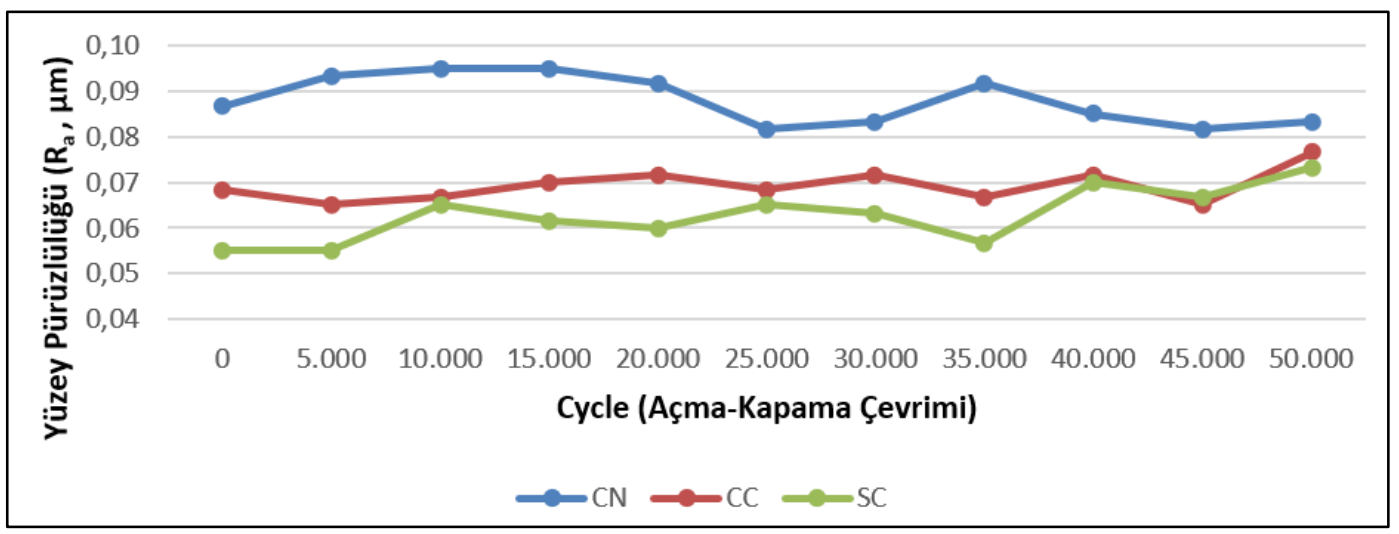

Şekil 7. Test sonucunda elde edilen ortalama yüzey pürüzlülükleri grafiği

Amortisörün ömür testleri boyunca gaz kayıpları Şekil 8'de gösterilmiştir. Şekil 7 ile karşılaştırıldığında, yüzey pürüzlülüğü değişimi ve mutlak büyüklüğü, amortisörün gaz kaybı ile ters orantı ile örtüşmektedir. Yani yüzey pürüzlülüğü düşük olan amortisörün gaz kaybı, yüzey pürüzlülüğü yüksek olan amortisöre göre çok daha az olmuş ve ömür testi boyunca yüzey pürüzlülüğündeki değişim ile amortisör gaz kaybındaki değişim tutarlı olarak görülmüştür.

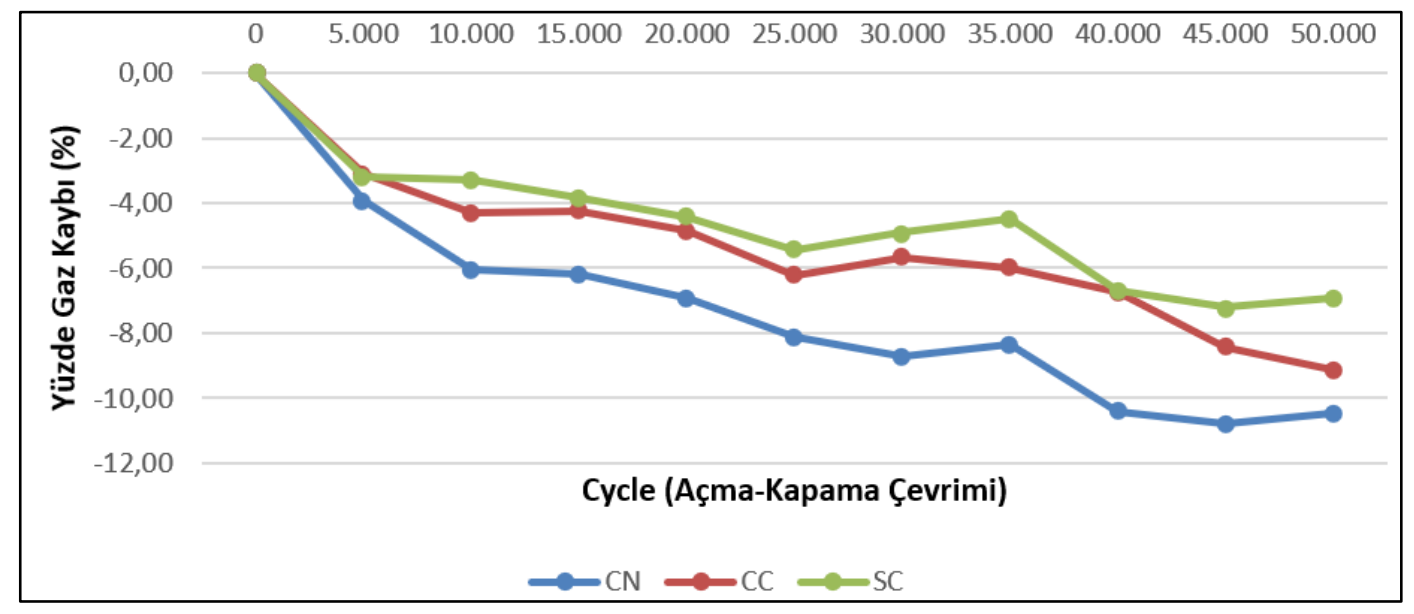

Şekil 8. Test sonucunda elde edilen ortalama yüzde gaz kayıplarl grafiği

Sürtünme kuvvetindeki değiş̧im ise Şekil 9'da gösterilmiştir. CC numunesindeki 40.000 çevrimden sonraki ani sürtünme kuvveti artışı haricinde sürtünme kuvvetleri nispeten yakın çıkmıştır. Sürtünme kuvvetine etki eden temel bileşenler, amortisördeki parçaların salgıları, sızdırmazlık parçalarının hareketli mil parçası ile oluşturduğu ara yüzey etkileşimindeki aşınma ve baskıdır. İlk 10.000 çevrime kadar lineer ilerleyen sürtünme kuvvetindeki değişim, yüzey pürüzlülükleri ile ilişkilendirilebilir. Yüzey pürüzlülüğü düşük olan amortisörün sürtünme kuvveti de düşük çıkmıştır. Dolayısıyla mil yüzey pürüzlülügüu düştükçe, sürtünme kuvvetinin de düştüğü görülmüştür. Şekil 9'daki CC numunesindeki 40.000 çevrimdeki ani artış, Şekil 8'deki gaz kaybı ilerleyişinde benzer etkide bir düşüş göstermemiştir. 


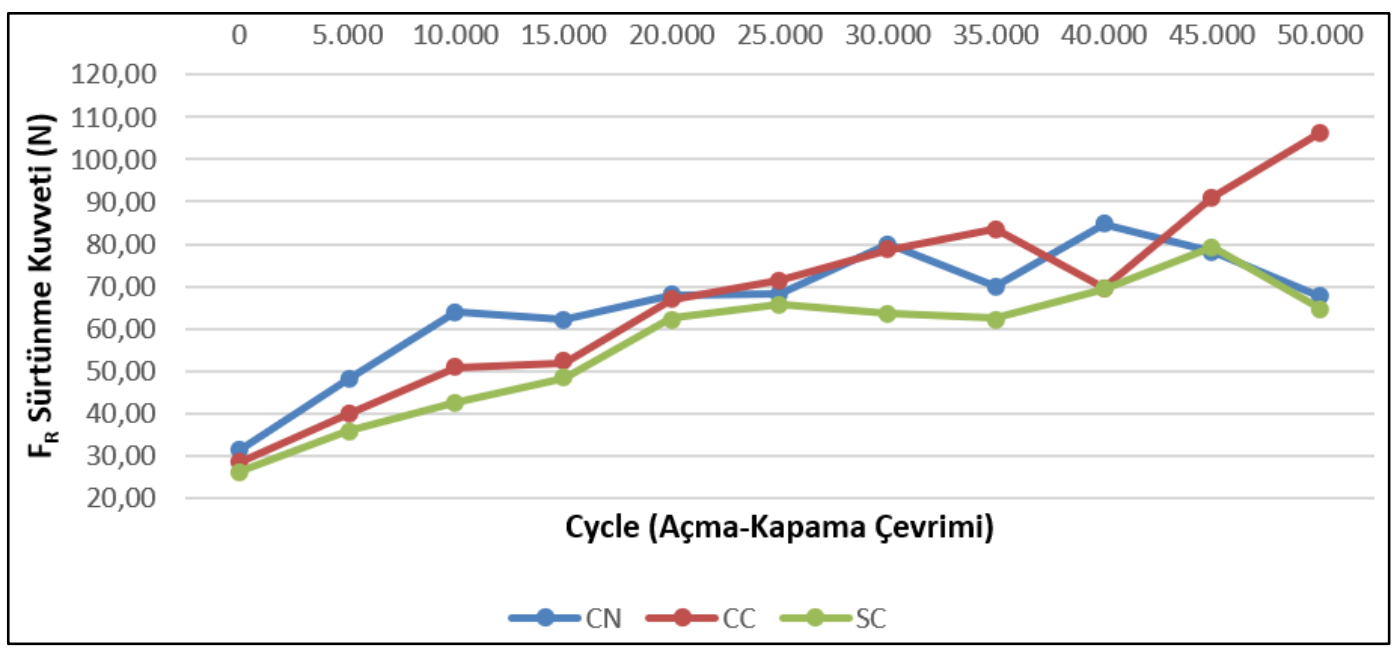

Şekil 9. Test sonucunda elde edilen ortalama sürtünme kuvvetleri grafiği

\subsection{Keçe Malzemesinin Amortisör Ömrüne Etkisi (PU Keçe)}

Keçe malzemesinin amortisör ömrüne olan etkisini incelemek için daha önce NBR ve QPQ mil ile yapılmış olan testlere karşın PU keçeli ve QPQ mil ile ayrıca numune çalışması yapılıp ömür testleri karşılaştırmalı olarak yorumlanmıştır. Bu sayede iki keçe malzemesinin amortisör ömrüne olan etkisi doğrudan görülebilmiştir. Tablo 6'da özellikleri verilmiş olan PU keçeli QPQ milli numuneye ömür testi uygulanmış, testin sonucu Tablo 7'de verilmiştir. Bu sonuçlara göre NBR keçeli ve nitrürasyon uygulanmış mil ile hazırlanan numunelerde FR sürtünme kuvvetinin 100 N'un altında kaldığı görülürken, PU keçeli, nitrürasyon uygulanmış mil ile hazırlanan numunelerde 200 N'a kadar ulaştığı gözlenmiştir. Ayrıca NBR keçeli amortisörlerde yağ kaybı 0,5 cc'yi geçmemiş iken, PU keçeli numunelerde 1,8cc'ye kadar yăg kaybı ölçülmüştür. Bununla birlikte, PU keçe daha rijit bir karakter göstermiş ve 113.000 çevrime kadar \%6,61'lik bir gaz kaybı göstermiştir. Ömür testleri sonucu mil yüzeylerinin optik mikroskop ve SEM görüntüleri Şekil 10'da görülmektedir. Hem krom kaplı hem de nitrürlenmiş millerde kayma yönünde makro ve mikro abrazif aşınma çiziklerine rastlanılmıştır. Dikey çizgilerin taşlama esnasında oluşan çizikler olduğu düşünülmektedir. Nitrürasyon uygulanmış mil yüzeyinin daha pürüzlü olduğu da dikkat çekmektedir. Krom kaplı numunelere göre başlangıç pürüzlülüğünün yüksek olması bunun sebebidir.

Tablo 6. PU keçe testindeki numune özellikleri

\begin{tabular}{|c|c|}
\hline$\ddot{O ̈ z e l l i k}$ & Dĕger \\
\hline Mil & $\varnothing 8 \mathrm{~mm}$ \\
\hline Boru İç Çap1 & $\varnothing 16 \mathrm{~mm}$ \\
\hline Kuvvet & $600 \mathrm{~N}$ \\
\hline Keçe & PU 94 ShR \\
\hline Çalışan Boy & $202 \mathrm{~mm}$ \\
\hline Yağ Viskozite İndeksi & 174 (ISO 2909) \\
\hline Yağ Kinematik Viskozite $\left(40^{\circ} \mathrm{C}\right)$ & $34,6 \mathrm{~mm}^{2} / \mathrm{s} \quad[13]$ \\
\hline Mil & Nitrürasyonlu $\left(0,8 \mu \mathrm{m} \mathrm{R} \mathrm{R}_{\mathrm{a}}\right)$ \\
\hline
\end{tabular}

\section{Bulgular ve Tartışma}

Yüzey pürüzlülüğü ve mil malzemesi ile uygulanan yüzey işlemleri değişkenleri ile yapılan ömür testleri sonucunda 10.000 çevrime kadar sürtünme kuvvetlerinin lineer olarak arttığ1 gözlenmiştir. 10.000 çevrim sonunda sürtünme kuvveti değişkenlik göstererek seyretmiştir. Bu değişkenliğin sebebi ise birden fazla etkinin toplamı olarak yorumlanmıştır. Örneğin keçe dudaklarının yıpranması sürtünme kuvvetini arttırırken, çalışma boyunca gaz kaybı yaşanması ise keçelere yapılan etki kuvvetini azalttığından, sürtünme kuvvetini de azaltma yönünde etki edecektir. 


\section{Journal of Characterization}

Tablo 7. PU keçeli amortisör ömür testi sonuçları

\begin{tabular}{crrrrrc}
\hline Çevrim & $\boldsymbol{F 1}$ & $\boldsymbol{F 2}$ & $\boldsymbol{F 3}$ & $\boldsymbol{F 4}$ & $\boldsymbol{F R}$ & $\begin{array}{c}\text { Kuvvet } \\
\boldsymbol{K a y b \boldsymbol { ~ }} \boldsymbol{\%}\end{array}$ \\
\hline 0 & 607,04 & 843,97 & 709,10 & 946,03 & 102,06 & 0,00 \\
5.000 & 604,92 & 805,57 & 742,45 & 943,10 & 137,53 & $-0,35$ \\
10.000 & 586,19 & 800,85 & 789,28 & $1.003,94$ & 203,09 & $-3,43$ \\
15.000 & 593,00 & 820,44 & 739,42 & 966,86 & 146,42 & $-2,31$ \\
20.000 & 601,26 & 833,75 & 740,33 & 972,82 & 139,07 & $-0,95$ \\
25.000 & 612,00 & 842,39 & 735,67 & 966,06 & 123,67 & 0,82 \\
30.000 & 592,05 & 829,21 & 734,09 & 971,25 & 142,04 & $-2,47$ \\
35.000 & 608,83 & 838,97 & 730,06 & 960,20 & 121,23 & 0,29 \\
50.000 & 585,54 & 813,61 & 725,90 & 953,97 & 140,36 & $-3,54$ \\
70.000 & 574,55 & 777,71 & 701,83 & 904,99 & 127,28 & $-5,35$ \\
78.000 & 581,14 & 775,98 & 686,94 & 881,78 & 105,80 & $-4,27$ \\
86.000 & 569,20 & 755,04 & 688,79 & 874,63 & 119,59 & $-6,23$ \\
94.000 & 566,66 & 746,27 & 674,30 & 853,91 & 107,64 & $-6,65$ \\
113.000 & 566,92 & 723,21 & 668,74 & 825,03 & 101,82 & $-6,61$ \\
121.000 & 533,51 & 706,46 & 674,02 & 846,97 & 140,51 & $-12,11$ \\
\hline
\end{tabular}
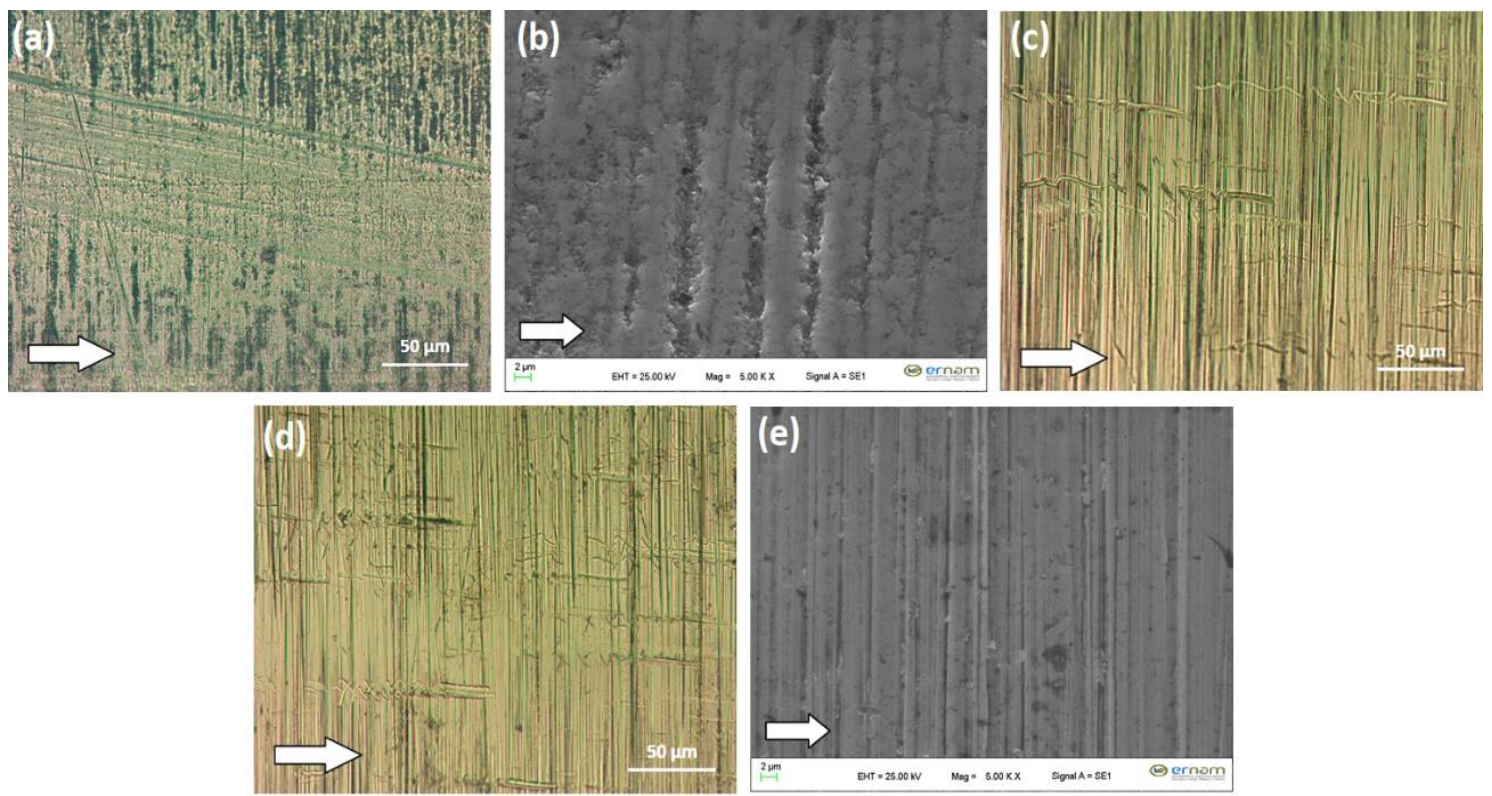

Şekil 10. Ömür testi sonrast yüzey optik mikroskop ve SEM görüntüleri: (a), (b) nitrürlenmiş C35 mil, (c), (d), (e) krom kaplı SS316 mil (oklar kayma yönünü göstermektedir)

Ömür testi boyunca $\mathrm{CN}$ numunelerinin pürüzlülüğü azalırken, $\mathrm{SC}$ ve $\mathrm{CC}$ numunelerinin pürüzlülüğü artmıştır. Yapılan yüzey pürüzlülüğü ölçümlerine göre ise, krom kaplamalı milin yüzey pürüzlülüğündeki artış hemen hemen tüm numunelerde aynı oranda ölçülürken, nitrürasyon uygulanmış 3 numunenin 2'sinde azalmış ancak birinde artmıştır. Ortalama olarak bakıldığında ise nitrürasyonlu numunelerde pürüzlülük düşmüştür. Dolayısıyla gazlı amortisör çalıştıkça krom kaplamalı numunelerde yüzey pürüzlülüğü artarken, nitrürasyon uygulanmış numunede yüzey pürüzlülüğü azalmıştır. 50.000 çevrim için test öncesi ve sonrası mutlak ortalama pürüzlülük değişimi ise $0,1 \mu \mathrm{m}$ olarak ölçülmüştür. Buna karşın bu değişimler, başlangıçtaki yüzey pürüzlülüğü değerlerine göre kuvvet kaybı etkisindeki mil sıralamasını etkilememiş, başlangıçtaki yüzey pürüzlülüğü düşük olan mil en yüksek ömür testi dayanımını vermiştir. Yalnızca yüzey pürüzlülüğünün etkisi değerlendirilmek istendiğinde Tablo 8 'de görülebileceği gibi yüzey pürüzlülüğü azaldıkça, kuvvet kaybı da yakın oranda azalmıştır. Dolayısıyla mil yüzey pürüzlülüğü amortisör ömrünü belirlemek için doğrudan etken olmuştur. 
Tablo 8. Ömür testi öncesi ve sonrasindaki ortalama yüzey pürüzlülü̆ü ve kuvvet kaybı değerleri

\begin{tabular}{cccc}
\hline Numune & $\begin{array}{c}\text { Test Öncesi Ortalama Yüzey } \\
\text { Pürü̈zlüllükleri }(\boldsymbol{R}, \boldsymbol{\mu m})\end{array}$ & $\begin{array}{c}\text { Test Sonrast Ortalama Yüzey } \\
\text { Pürü̈zlüllükleri }(\boldsymbol{R}, \boldsymbol{\mu m})\end{array}$ & $\begin{array}{c}\text { Kuvvet } \\
\text { Kaybt \% }\end{array}$ \\
\hline CN & 0,09 & 0,08 & $-10,5$ \\
CC & 0,07 & 0,08 & $-9,1$ \\
SC & 0,06 & 0,07 & $-6,9$ \\
\hline
\end{tabular}

50.000 çevrim sonunda en çok gaz kaybı $\mathrm{CN}$ numunelerinde görülürken, en az gaz kaybı SC numunelerinde gözlenmiştir. Yapılan tüm testlerin sonucunda pürüzlülük azaldıkça gaz kaybı ciddi oranda azalmıştır. Ancak sürtünme kuvveti dikkate alındığında $\mathrm{CN}$ ve $\mathrm{SC}$ numunelerine göre sürtünme kuvveti CC numunelerinde ciddi oranda artmıştır. Mil yüzey pürüzlülüğünün amortisör ömrüne etkisi çalışmalarında amortisör salgısı ve kullanılan tüm diğer bileşenlerin aynı olması, aynı basınçlarda gaz şarj edilmiş olmaları yapılan testlerin mukayesesinin doğruluğunu arttırmakta önemli rol oynamıştır.

NBR ve PU keçe kullanımının amortisörün kullanım ömrüne olan etkisinin incelenmesi sonucunda, PU keçeli amortisörün, NBR keçeli amortisöre göre sürtünme kuvvetinde 2 kat artış vermesine karşın, sızdırmazlık anlamında 2 katın üzerinde performans göstererek çalışma ömrü sağladığı görülmüştür. Sürtünme kuvvetindeki artış aynı zamanda sızdırmazlık anlamında daha büyük bir kuvvet ile mil-keçe ara yüzeyinde etkileşim olduğunu göstermektedir. Mil-keçe yüzeyindeki etkileşimi bir katsayı olarak düşünürsek, benzer oranda amortisör ömrünün arttı̆ğ da söylenebilir. Ancak PU keçeli amortisörün ömür testinde görülebileceği gibi 113.000 çevrime kadar \%6,61 basınç kaybı yaşanmış iken, 121.000 çevrimde $\% 12,11$ 'lik ani bir basınç kaybı yaşanmıştır. Aynı zamanda NBR keçeli numunelerde 0,5 cc altında bir yağ kaybı görülür iken PU keçeli amortisör numunesinde 1,8 cc'ye kadar yağ kaybı ölçülmüştür. Bu ani basınç kaybı ve yağ kaybının tartışmasız sebebi keçe dudaklarındaki deformasyondur. Yüksek sürtünme kuvvetinden dolayı keçe dudağında biriken gerilme deformasyon ile sonuçlanmıştır.

Tablo 8'deki sonuçlara göre yüzey pürüzlülüğü düştükçe gaz kaybının da daha az olduğu görülmüş ve yüzey pürüzlülüğünün gazlı amortisörün çalışma ömründe doğrudan etkili olduğu tespit edilmiştir. Mil yüzeyindeki pürüzlülükte yapılabilecek iyileştirme çalışmalarının doğrudan amortisör ömrünü iyileştireceği açıktır. Ancak pürüzlülük alanında yapılacak olan iyileştirmeler bir eşik noktasından sonra yapışmaya sebep olabilir. Bengisu ve ark. [6] yapmış oldukları çalışmada yüzey pürüzlülüğündeki iyileşmenin kayma hareketinin gücünü arttırdığını, ancak belli bir eşik geçildiğinde yapışma görülebileceğini teorik olarak ifade etmişler ve bu eşik değerin kabaca deformasyon kuvvetlerinin büyüklüğüne karşılık geldiğini söylemişlerdir. Gazlı amortisörün çalışma ömrüne etki edebilecek farklı viskozitelerde yağ kullanımının etkisi, çalışma salgısına etki edebilecek farklı yataklama uzunluklarının etkisi, keçe dudaklarına uygulanan farklı basınçların etkisi (düşük ve yüksek basınç) ve mil çapı değişkenliğinin ömür testine olan etkisinin ayrı ayrı çalışılması ve yorumlanmasının bu çalışmayı tamamlayıcı olarak rol oynayacağı da düşünülmektedir. Bengisu ve ark. [6] ayrıca temas bölgelerindeki direnç kuvvetlerinin toplamının sürtünme kuvvetini oluşturduğunu belirtmişlerdir. Dolayısıyla mil çapındaki artışın, temas bölgesi alanını arttıracağından sürtünme kuvvetini arttırma yönünde de bir etki gösterebileceği teorik olarak ifade edilmiştir. Devlen ve ark. [7] yapmış oldukları çalışmada K751 itici yaylı karbon katkılı PTFE piston keçesine dikkat çekmişlerdir. Bu çalışmada yapılan NBR ve PU keçe testlerine ve sonuçlarına istinaden önerilen bu keçenin de test edilmesi hem kıyaslama hem doğrulama açısından önerilmektedir. Gunes ve ark. [14] ise yaptıkları çalışmada termo reaktif difüzyon (TRD) yöntemiyle kromlama işleminin AISI 5115 çeliğinin karakterizasyon özelliklerine etkisini araştırmışlardır. Kimyasal ve fiziksel buhar biriktirme yöntemleri ile elde edilen kaplama kalılıklarına benzer kalınlıklarda ve sert kaplamalar elde edilebildiği için yöntemin amortisör millerinde kullanımı da araştırılabilecek bir başka konudur.

\section{Sonuçlar}

$\mathrm{Bu}$ çalışmada, aynı çaplarda ve aynı özelliklerde hazırlanmış olan gazlı amortisörlerde nitrürasyon uygulanmış C35, krom kaplanmış C45 ve krom kaplanmış SS316 olmak üzere 3 farklı milin ve farklı özelliklerdeki keçelerin amortisör ömrüne olan etkisi tribolojik olarak araştırılmıştır. Bulunan sonuçlar şu şekilde özetlenebilir: 
1. Ömür testi boyunca $\mathrm{CN}$ numunelerinin pürüzlülüğü azalırken, $\mathrm{SC}$ ve $\mathrm{CC}$ numunelerinin pürüzlülüğü artmıştır.

2. Yüzey pürüzlülüğü düşük olan numunelerin kuvvet kaybı da az olmuştur. 50.000 çevrim sonucunda en çok gaz kaybı CN numunelerinde görülürken, en az gaz kaybı SC numunelerinde gözlenmiştir. Numunelerin ömür testi boyunca yüzey pürüzlülüğündeki değişị, numunelerin gaz kaybı sıralamasını değiştirebilecek kadar büyük bir etki sağlamamış olsa da yüzey pürüzlülük değerlerine göre tespit edilen gaz kayıpları sonuçları değerlendirildiğinde yüzey pürüzlülüğükuvvet kaybı etkileşimi doğru orantılı izlenmiştir.

3. Sürtünme kuvveti dikkate alındığında $\mathrm{CN}$ ve $\mathrm{SC}$ numunelerine göre sürtünme kuvveti $\mathrm{CC}$ numunelerinde ciddi oranda artmıştır.

4. PU keçeli amortisörün, NBR keçeli amortisöre göre sürtünme kuvvetinde 2 kat artış vermesine karşın, sızdırmazlık anlamında 2 katın üzerinde performans göstererek çalışma ömrü sağladığı görülmüştür.

\section{Kaynaklar}

[1] Y. Soydan and L. Ulukan, Temel Triboloji. Kopisan, 2013.

[2] S. Kessel, "Publication of Stabilus Full Year Results for Fiscal Year 2018, Annual Report," 2018. [Online]. Available: http://ir.stabilus.com/download/ companies/stabilus/Annual\%20Reports/LU1066226637-JA-2017-EQ-E-00.pdf. [Accessed May 17, 2021].

[3] K. Sakarya and S. Karakoç, "Ağır hizmet uygulamalarında kullanılan sızdırmazlık elemanlarında yenilikler,” In Proc. VI. Ulusal Hidrolik Pnömatik Kongresi, 2011, pp. 57-72.

[4] A. Yildiz, O. Kopmaz and Y. Gokyer, "Binek araçlarda kullanılan gazlı pistonlu bagaj kapağı açma kapama mekanizmalarının incelenmesi”, Uludağ University Journal of The Faculty of Engineering, vol. 20, pp. 1-10, 2015.

[5] J. Boblet and M. Kreutz, "TUFFTRIDE / QPQ Process," 2000. [Online]. Available: http://www.houstonunlimitedinc.com/pdf/Tufftride.pdf. [Accessed May 17, 2021].

[6] M. T. Bengisu and A. Akay, "Stick-slip oscillations: Dynamics of friction and surface roughness", The Journal of the Acoustical Society of America, vol. 105, pp. 194-205, 1999.

[7] O. Devlen and K. Sakarya, "PTFE ürünlerinde gelişmeler ve sızdırmazlık teknolojisinde kullanım alanları" In Proc. VI. Ulusal Hidrolik Pnömatik Kongresi, 2011, pp. 349-364.

[8] W. Cai, F. Meng, X. Gao and J. Hu, "Effect of QPQ nitriding time on wear and corrosion behavior of 45 carbon steel", Applied Surface Science, vol. 261, pp. 411-414, 2012.

[9] J.-I. Lee, "The development of gas seal lip technology on piston rod for reducing a friction force on moving gas spring elevation", Journal of the Korea AcademiaIndustrial cooperation Society, vol. 16, pp. 7166-7175, 2015.

[10] G. D. Benedetto, M. Organisciak, G. Popovici and A. Stijepić, "Film thickness prediction of radial lip seal”, FME Transactions, vol. 37, pp. 87-90, 2009.

[11] D. W. Irman, and H. Bollman, "Skf sealing NBR00450 (NB9016) technical datasheet", 2010.

[12] Kastas Sealing Technologies A.S., "PU9201 Material Datasheet". 2012. [Online]. Available: http://www.hydrokrak.pl/!data/pdf/Kastas_NewProducts Catalogue_EN.pdf. [Accessed May 17, 2021].

[13] Shell, "Shell Spirax S2 ATF AX Datasheet". 2015. [Online]. Available: http://www.ozgunshell.com/yuklemeler/shell-spirax/SHELL\%20SPIRAX\%20 S2\%20ATF\%20AX.pdf. [Accessed May 17, 2021].

[14] I. Gunes and A. G. Celik, "Surface characterization of chromized AISI 5115 steel by thermo reactive diffusion method", Journal of Characterization, vol. 1, pp. 61-65, 2021. 